\title{
Characterization of rhizobia isolated from legume species within the genera Astragalus and Lespedeza grown in the Loess Plateau of China and description of Rhizobium loessense sp. nov.
}

\author{
Correspondence \\ Wen Xin Chen \\ wenxin_chen@263.net
}

\author{
Ge Hong Wei, ${ }^{1,2}$ Zhi Yuan Tan, ${ }^{1}$ Ming E Zhu, ${ }^{2}$ En Tao Wang, ${ }^{3}$ \\ Su Zhen $\operatorname{Han}^{1}$ and Wen Xin Chen ${ }^{1}$ \\ ${ }^{1}$ College of Biological Sciences, China Agricultural University, Beijing 100094, People's \\ Republic of China \\ ${ }^{2}$ College of Resource and Environment Sciences, Northwest Science and Technology \\ University of Agriculture and Forestry, Yangling Shaanxi 712100, People's Republic of China \\ ${ }^{3}$ Departamento de Microbiología, Escuela Nacional de Ciencias biológicas, Instituto Politécnico \\ Nacional, México, DF, Mexico
}

\begin{abstract}
Twenty-nine rhizobial isolates from root nodules of Astragalus and Lespedeza spp. growing in the Loess Plateau of China were characterized by numerical taxonomy, RFLP and sequencing of PCR-amplified 16S rRNA genes, measurement of DNA G +C content, DNA-DNA relatedness and cross-nodulation with selected legume species. Based on the results of numerical taxonomy, the isolates formed two clusters ( 1 and 2) with some single isolates at a similarity level of $82 \%$. Cluster 1 contained six isolates from Astragalus and Lespedeza spp. Cluster 2 consisted of nine isolates from Astragalus spp. DNA relatedness was greater than $80 \%$ among isolates within cluster 2. Phylogenetic analysis based on 16S rRNA gene sequences showed that CCBAU $7190 \mathrm{~B}^{\top}$, representing cluster 2 , was closely related to Rhizobium galegae and Rhizobium huautlense. DNA-DNA relatedness between CCBAU $7190 \mathrm{~B}^{\top}$ and reference strains of $R$. galegae, $R$. huautlense and other related species ranged from 0 to $48 \cdot 6 \%$. The cluster 2 isolates could also be differentiated phenotypically from related species. Based on these data, a novel species, Rhizobium loessense sp. nov., is proposed for cluster 2, with the type strain CCBAU $7190 \mathrm{~B}^{\top}$ $\left(=\mathrm{AS} 1.3401^{\mathrm{T}}=\mathrm{LMG} 21975^{\mathrm{T}}\right)$.
\end{abstract}

\section{INTRODUCTION}

To date, more than 30 species have been described for legume-associated symbiotic nitrogen-fixing bacteria within the genera Allorhizobium, Azorhizobium, Bradyrhizobium, Mesorhizobium, Rhizobium, Sinorhizobium and Methylobacterium in the $\alpha$-Proteobacteria, as well as Burkholderia and Ralstonia in the $\beta$-Proteobacteria (Chen et al., 2001; Moulin et al., 2001). However, the diversity of these bacteria is still far from clear compared with the great number and vast distribution of their leguminous hosts. Also, in these studies, rhizobia were mainly isolated from a small

Published online ahead of print on 9 May 2003 as DOI 10.1099/ ijs.0.02031-0.

The GenBank/EMBL/DDBJ accession number of the $16 \mathrm{~S}$ rDNA sequence of strain CCBAU $7190 B^{\top}$ is AF364069.

Details of the sources of reference strains used in this study and a $16 \mathrm{~S}$ rDNA-based phylogenetic tree showing a wider selection of reference rhizobial strains are available as supplementary material in IJSEM Online. proportion of legumes, mainly crops, such as soybean, common bean and alfalfa. Recently, some rhizobia have been characterized from wild and tree legumes and several novel taxa were proposed on the basis of these studies (Squartini et al., 2002; Wei et al., 2002). Therefore, the characterization of more isolates from different leguminous species is necessary in order to understand the diversity and evolution of rhizobia.

The genus Astragalus, including 1500-2000 species, is one of the largest genera in the family Leguminosae. Many species within this genus are important resources for production of herbal medicines or foliage for wild animals. Nodulation of 90 Astragalus species has been reported (Allen \& Allen, 1981), although very little taxonomic work has been done on the microsymbionts associated with these species. Rhizobia isolated from Astragalus sinicus in China have been assigned to Mesorhizobium huakuii (Chen et al., 1991). The genetic diversity among rhizobia from Astragalus adsurgens in different geographical regions of China has been investigated, and bacterial lineages related to Mesorhizobium, 
Rhizobium and Sinorhizobium were reported (Gao et al., 2001). Different rhizobial groups were also defined among isolates from other Astragalus species in China (Wang \& Chen, 1996) and in other countries (Laguerre et al., 1997; Murooka et al., 1993; Novikova et al., 1994; Wdowiak \& Malek, 2000).

About 100 species have been described in the leguminous genus Lespedeza, including herbs, semishrubs and shrubs (Allen \& Allen, 1981), and 70 Lespedeza species have been found in China. The leaves, stems and roots of many of these plants are used as herbal medicines. Lespedeza cyrtobotrya, Lespedeza buergeri, Lespedeza bicolor and some other species are used for treating lung infections, for diuresis or for stopping bleeding; Lespedeza pilosa, Lespedeza tomentosa, Lespedeza chinensis and some others are conducive to the health of the stomach. The flowers of some species are also important honey resources. Some rhizobial isolates from Lespedeza species in China and in the USA have previously been characterized (Yao et al., 2002). Most isolates from the USA were identified as Bradyrhizobium japonicum and Bradyrhizobium elkanii. The isolates from China were classified as Sinorhizobium saheli and a novel species, Bradyrhizobium yuanmingense, as well as some unnamed strains.

Legume species within the genera Astragalus and Lespedeza, as well as many others, are found in the Loess Plateau, which includes parts of the provinces of Shanxi, Shaanxi, Gansu and Ningxia. Located in the north-western region of China, these areas have semi-arid climates and soils poor in organic matter. The leguminous plants that grow there are normally drought-enduring and are held in high esteem as foliage, green-manure crops or honey resources and play an important role in preventing soil erosion and in improving the adverse environment. In recent years, we have investigated rhizobial resources and characterized rhizobial isolates from Amorpha fruticosa, Glycyrrhiza spp., Gueldenstaedtia spp. and some other plants in this region according to their geographical origin or host origin (Peng et al., 2002; Tan et al., 1999; Wang et al., 1999). Novel species within the genera Rhizobium (Tan et al., 2001; Wei et al., 2002), Sinorhizobium (Wei et al., 2002) and Mesorhizobium (Wang et al., 1999) have been described for some of these isolates. This research indicates that rhizobia in temperate regions are as diverse as those in tropical areas.

Considering the potential value of Astragalus and Lespedeza species in sustainable agriculture and the insufficient study on the diversity of rhizobia associated with these plants, we decided to collect and characterize rhizobia associated with these two plant genera in the Loess Plateau. In this research, 29 nodule isolates from Astragalus and Lespedeza species growing in the Loess Plateau were characterized. The aims of the research were to examine the diversity and to clarify the taxonomic position of the isolates by both phenotypic and genetic analyses.

\section{METHODS}

Isolates and strains. Root nodules were collected from 11 leguminous members of Astragalus, Lespedeza and Hedysarum in fields of Shaanxi, Gansu and Ningxia provinces (Table 1). Nodules were collected from wild plants growing in soils poor in organic matter and without the addition of fertilizer. Rhizobia were isolated from fresh nodules by the standard method on YMA medium (Vincent, 1970). Single colonies were picked and checked for purity by repeated streaking and by microscopic examination. Nodulation on the original host plant of each isolate was checked in glass tubes half-filled with vermiculite as described by Vincent (1970). Inoculated plants were grown in a greenhouse at $23{ }^{\circ} \mathrm{C}$ during the day and $12{ }^{\circ} \mathrm{C}$ during the night and were illuminated with 10000-20000 lux for $14 \mathrm{~h} \mathrm{day}^{-1}$. Details of the 37 reference strains used in this study are available as supplementary material in IJSEM Online.

Phenotypic characterization and numerical taxonomy. One hundred and thirty-six phenotypic features, including utilization of sole carbon and nitrogen sources, resistance to antibiotics, tolerance of dyes and chemicals, temperature and $\mathrm{pH}$ ranges for growth and some physiological and biochemical reactions described previously (Gao et al., 1994) were examined. Generation times of the isolates were determined spectrophotometrically (Yelton et al., 1983) in YM broth (Vincent, 1970).

UPGMA (Sneath \& Sokal, 1973) was used for clustering analysis of phenotypic features. The mean similarity for each isolate within a cluster was estimated to present the phenotypic variation in the cluster, as described previously, and the central isolate, representative of the cluster, was identified as the highest mean similarity holder (Sneath \& Sokal, 1973).

PCR-based RFLP of 16S rRNA genes. Procedures described previously (Wang et al., 1998) were used for PCR amplification of almost-complete 16S rRNA genes with primers P1 and P6 (Tan et al., 1997), for digestion of the PCR products with restriction endonuclease MspI, Hinfl, HaeI or RsaI and for separation of the digested fragments in $3.0 \%$ agarose gels. Similarities $\left(S_{\mathrm{j}}\right)$ among bacteria were estimated using the formula $S_{\mathrm{j}}=(a+b) /(a+b+2 c)$, where $a$ is the number of bands unique to strain $\mathrm{A}, b$ is the number of bands unique to strain $\mathrm{B}$ and $c$ is the number of bands common to the two strains. A dendrogram showing phylogenetic relationships among the bacteria was constructed by using the UPGMA method (Sneath \& Sokal, 1973).

Phylogenetic analysis of 16S rRNA genes. Full-length $16 \mathrm{~S}$ rRNA genes (1500 bp) were amplified, cloned and sequenced as described previously (Tan et al., 1997). The 16S rDNA sequences obtained and those of related bacteria from the GenBank database were aligned using the PILEUP program in the GCG package (Genetics Computer Group, 1995). Sequence similarities among the $1500 \mathrm{bp}$ sequences were calculated and a phylogenetic tree was generated and bootstrapped with 1000 subsamples using CLUSTAL W version 1.7 (Thompson et al., 1994). The tree was visualized with the TreeView program (Page, 1996).

Estimation of DNA G+C content and DNA-DNA relatedness. DNAs were extracted and purified by a standard method (Marmur, 1961). DNA base compositions were determined using the thermal melting protocol (De Ley, 1970) with Escherichia coli K-12 as standard. Levels of DNA relatedness were estimated by measurement of the initial reassociation rate (De Ley et al., 1970).

Distinctive features and host range of the novel group. Distinctive features were chosen by comparing the phenotypic features of the nine isolates within cluster 2 with those of the most closely related species, Rhizobium galegae and Rhizobium huautlense. In order to test the host range of the novel group, plants inoculated with the rhizobial isolates were grown in pots filled with vermiculite 
Table 1. Isolates used in this research

CCBAU, Culture Collection of Beijing Agricultural University, Beijing, China. All isolates were obtained from locations in north-western China. Details of reference strains are available as supplementary material in IJSEM Online.

\begin{tabular}{|c|c|c|}
\hline Strain/isolate & Host plant & Geographical origin \\
\hline \multicolumn{3}{|l|}{ Cluster 1 (Rhizobium sp.) } \\
\hline CCBAU 71291 & Astragalus complanatus & Gansu \\
\hline CCBAU 71394, CCBAU 71395 & Astragalus adsurgens & Shaanxi \\
\hline CCBAU 71218 & Lespedeza davidii & Ningxia \\
\hline CCBAU 71323 & Lespedeza cyrtobotrya & Shaanxi \\
\hline CCBAU 71199 & Hedysarum scoparium & Ningxia \\
\hline \multicolumn{3}{|l|}{ Cluster 2 (Rhizobium loessense sp. nov.) } \\
\hline CCBAU 71264, CCBAU 7190A, CCBAU 7190B ${ }^{\mathrm{T}}$ & A. complanatus & Gansu \\
\hline CCBAU 71288, CCBAU 71309 & A. complanatus & Shaanxi \\
\hline CCBAU 71240 & Astragalus scobwerrimus & Gansu \\
\hline CCBAU 71289 & A. scobwerrimus & Ningxia \\
\hline CCBAU 71295 & Astragalus chrysopterus & Shaanxi \\
\hline CCBAU 71291 & A. chrysopterus & Gansu \\
\hline \multicolumn{3}{|l|}{ Other rhizobial isolates } \\
\hline CCBAU 71148, CCBAU 71169 & A. complanatus & Shaanxi \\
\hline CCBAU 71272 & A. complanatus & Gansu \\
\hline CCBAU 71145 & A. scobwerrimus & Shaanxi \\
\hline CCBAU 71236 & A. scobwerrimus & Gansu \\
\hline CCBAU 71155 & Astragalus mongholicus & Shaanxi \\
\hline CCBAU 671286 & A. adsurgens & Gansu \\
\hline CCBAU 71152 & A. adsurgens & Shaanxi \\
\hline CCBAU 71Y12 & Lespedeza bicolor & Shaanxi \\
\hline CCBAU 71069 & Lespedeza davurica & Shaanxi \\
\hline CCBAU 71312 & Lespedeza virgata & Shaanxi \\
\hline CCBAU 71308, CCBAU 71075 & Lespedeza cyrtobotrya & Shaanxi \\
\hline CCBAU 71263 & Lespedeza sp. & Gansu \\
\hline
\end{tabular}

moistened with N-free plant nutrient solution (Vincent, 1970) for 1 month before nodulation and nitrogen fixation was recorded. Crossnodulation was tested among the isolates within the novel cluster and their host plants, as well as among representatives of the novel groups and recommended legume species (Graham et al., 1991), including Astragalus sinicus, Medicago sativa, Galega orientalis, Lotus corniculatus, Vigna sinensis, Glycine max, Trifolium repens, Phaseolus vulgaris and Caragana korshinskii.

\section{RESULTS AND DISCUSSION}

Thanks to the application of molecular biological methods, the taxonomy of root- and/or stem-nodulating bacteria has changed dramatically in the last two decades. Polyphasic taxonomy covering phenotypic, genomic and phylogenetic characteristics has generally been used. In this study, we characterized 29 nodule isolates from Astragalus and Lespedeza species in the Loess Plateau of China by means of a polyphasic approach.

\section{Phenotypic characterization and numerical taxonomy}

In this study, the 29 isolates used were fast-growing rhizobia that formed single colonies with diameters of $2-3 \mathrm{~mm}$ within 3 days on YMA. All of them were effective symbionts, as evidenced by the formation of pink nodules on their original hosts. None of the tested strains could use adipate, inulin, sorbitol or syringic acid as sole carbon sources. All of the strains were sensitive to kanamycin $\left(100-300 \mu \mathrm{g} \mathrm{ml}^{-1}\right)$ and neomycin $\left(100\right.$ and $\left.300 \mu \mathrm{g} \mathrm{ml}^{-1}\right)$. No strain could grow in medium supplied with $0 \cdot 1 \%$ gentian violet or methylene blue or $5 \% \mathrm{NaCl}$. They could not grow at $\mathrm{pH} 4.0$ or at $4{ }^{\circ} \mathrm{C}$. All strains used L-arginine as a sole nitrogen source and were resistant to the antibiotics bacitracin (5-300), erythromycin (5), neomycin (5) and polymyxin (5) (all $\mu \mathrm{g} \mathrm{ml}^{-1}$ ). All strains grew in medium supplemented with $0 \cdot 1 \%$ Bismarck brown, Congo red, erythrosin, neutral red, sodium deoxycholate and sodium nitrite and with $1 \cdot 0(\mathrm{w} / \mathrm{v}) \mathrm{NaCl}$.

The 102 features that varied among the tested strains were used for cluster analysis. Based on these results (Fig. 1), most of the defined species could be separated at a similarity level of $82 \%$. The exceptions were Rhizobium tropici and Rhizobium hainanense, which were separated at $86 \%$ similarity. Similarities of $96-65 \%$ were found among the novel isolates (Fig. 1), indicating that these isolates represented phenotypically diverse populations. Since the characteristics covered physiological, biochemical and 


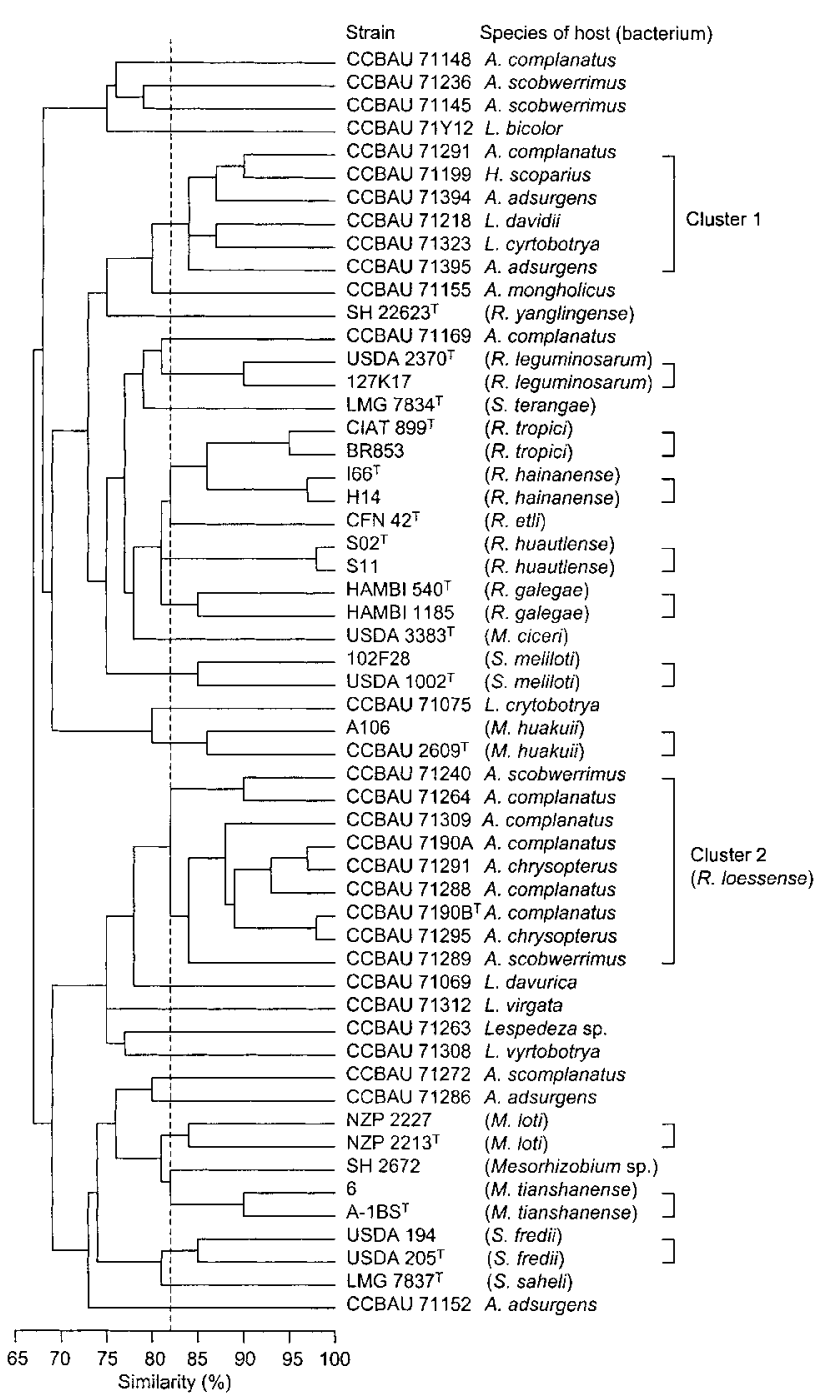

Fig. 1. Dendrogram showing the results of numerical taxonomy. The coefficient $S_{\text {sm }}$ and UPGMA (Sneath \& Sokal, 1973) were used for clustering analysis of phenotypic features.

environmental factors and resistance to chemicals and antibiotics, the phenotypic diversity also indicated that the isolates represented a diverse gene pool. The diversity within the rhizobial population could offer advantages in survival and adaptation of nodulation in different environments.

Fifteen of the 29 isolates formed two clusters at a similarity level of $83 \%$, while the other isolates were single branches (Fig. 1). These groups and single branches were different from the reference species, and they might infer different species or genera. Some important aspects of the two clusters are described below.

Cluster 1 consisted of six fast-growing isolates from five host species within three genera, Astragalus complantus, Astragalus adsurgens, Hedysarum scoparium, Lespedeza davidii and Lespedeza cyrtobotrya. The mean similarity for the isolates ranged from $84 \%$ for CCBAU 71395 to $91 \%$ for CCBAU 71199; the latter was chosen as the central isolate. Colonies were $2-3 \mathrm{~mm}$ in diameter after 3 days on YMA at $28^{\circ} \mathrm{C}$. All isolates in this cluster produced acid in YMA, and all isolates grew in Luria-Bertani (LB) broth.

Cluster 2 contained nine isolates from Astragalus scobwerrimus, Astragalus complanatus and Astragalus chrysopterus. The mean similarities ranged from 83 to $99 \%$. CCBAU $7190 \mathrm{~B}^{\mathrm{T}}$ was chosen as the central isolate. They were fast-growing, acid-producing bacteria with a generation time of $2 \cdot 2-3 \cdot 4 \mathrm{~h}$ in $\mathrm{YM}$ broth, as determined spectrophotometrically. No growth of these isolates was observed in LB broth.

Numerical taxonomy has been used for grouping bacteria and for offering descriptive features for species. Clusters formed in numerical taxonomy often correspond to genomic groups defined by DNA-DNA hybridizations and other genomic analyses (Chen et al., 1991, 1995, 1997; de Lajudie et al., 1994). Therefore, the grouping results obtained in this approach could be a basis for further taxonomic study. Since cluster 1 consisted of only a few isolates, we did not characterize it further and instead focused on cluster 2 .

\section{PCR-RFLP of 16S rRNA genes}

As a rapid method, this technology has been used for grouping and identifying rhizobia. The grouping results of PCR-RFLP patterns of 16S rRNA genes agree well with those of multilocus enzyme electrophoresis, numerical taxonomy and sequencing of 16S rRNA genes (Laguerre et al., 1994; Tan et al., 1999; Wang et al., 1998, 1999). Following the grouping results from numerical taxonomy, three cluster 2 isolates, CCBAU $7190 \mathrm{~B}^{\mathrm{T}}$, CCBAU $7190 \mathrm{~A}$ and CCBAU 71240, and reference strains from defined species were chosen for this technique. The three representative isolates of cluster 2 had very similar patterns, with one or two bands different in one or another digestion with MspI, Hinfl, HaeI or RsaI (not shown). Distinctive patterns were observed among the rhizobia in cluster 1 and other species (not shown). In a dendrogram constructed based upon the PCR-RFLP patterns of 16S RNA genes (Fig. 2), four groups corresponding to the genera Bradyrhizobium, Sinorhizobium, Mesorhizobium and Rhizobium could be divided at the level of $80 \%$ similarity. Isolates of cluster 2 formed a subgroup within the genus Rhizobium, together with $R$. galegae and $R$. huautlense. These results indicated that cluster 2 was also a group based upon 16S rRNA gene sequences and it was probably related to $R$. galegae.

\section{Sequencing of 16S rDNA and its phylogeny}

Two independent clones of PCR-amplified 16S rDNA from the central isolate CCBAU $7190 \mathrm{~B}^{\mathrm{T}}$ of cluster 2 were sequenced. Sequences of the two clones were identical. In the reconstructed phylogenetic tree (Fig. 3), the phylogenetic relationships among the defined species are similar to those 


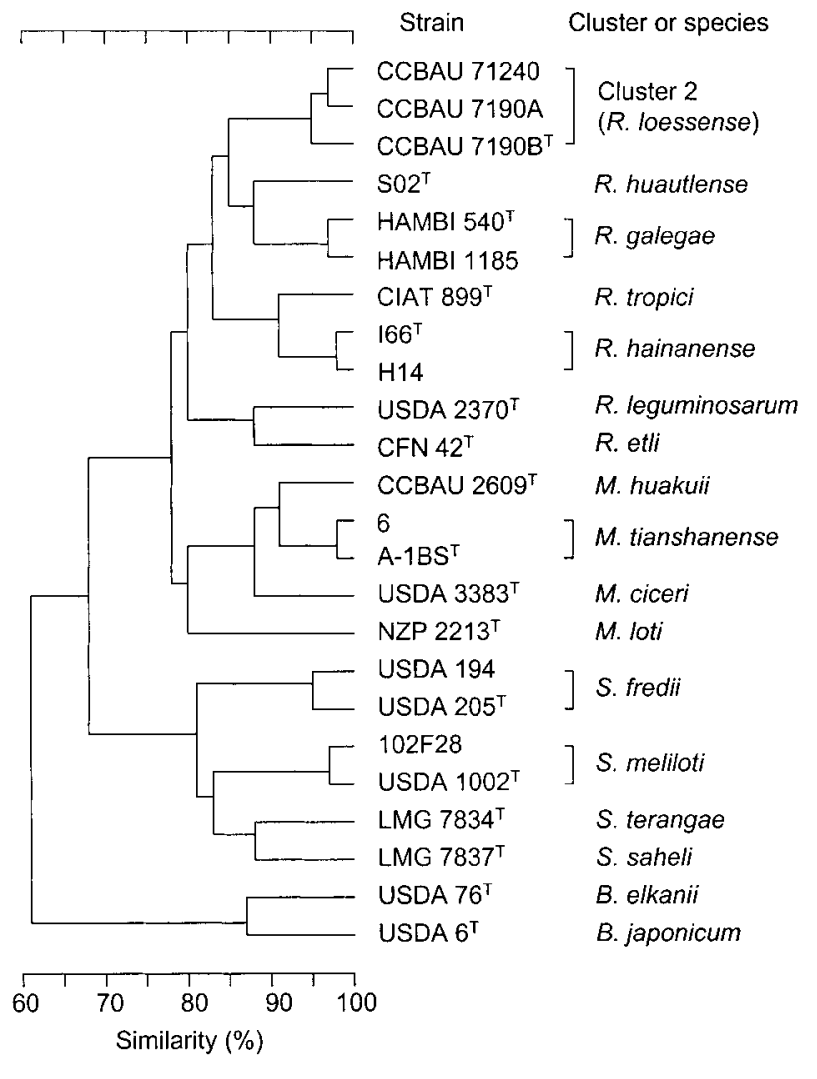

Fig. 2. Dendrogram showing relationships among the novel isolates and reference strains revealed by PCR-RFLP of $16 S$ rRNA genes. The coefficient $S_{\mathrm{j}}$ and the UPGMA method were used for the estimation of similarity and clustering analysis (Sneath \& Sokal, 1973).

in previously reported trees (de Lajudie et al., 1994, 1998a, b; Tan et al., 1997; Wang et al., 1999). The genera Azorhizobium, Bradyrhizobium, Mesorhizobium and Sinorhizobium are monophyletic groups; an extended tree including these genera is available as supplementary material in IJSEM Online. The species within the genus Rhizobium form a polyphyletic group. Nine Rhizobium species, including the type species, Rhizobium leguminosarum, formed a monophyletic group. The cluster 2 isolate CCBAU $7190 \mathrm{~B}^{\mathrm{T}}, R$. galegae and $R$. huautlense formed another monophyletic group and linked more closely to Agrobacterium species than to other Rhizobium species. This Rhizobium-Agrobacterium group was also polyphyletic, because Agrobacterium vitis and Allorhizobium undicola formed two long branches within the group. The $16 \mathrm{~S}$ rDNA sequence similarities between CCBAU $7190 \mathrm{~B}^{\mathrm{T}}$ and $R$. galegae and $R$. huautlense were respectively 96.8 and $97.5 \%$, and were greater than those between CCBAU $7190 \mathrm{~B}^{\mathrm{T}}$ and other species within the genera Agrobacterium and Rhizobium ( $<95 \cdot 0 \%)$.

Since $R$. galegae has been grouped into the phylogenetic branch of Agrobacterium species, the taxonomic position of

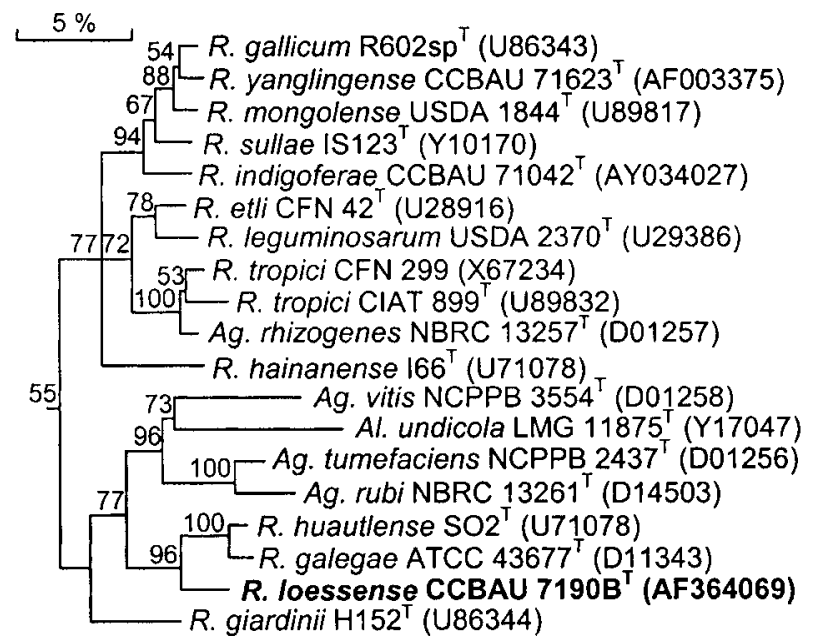

Fig. 3. Phylogenetic tree based on 16S rDNA sequences showing the position of the novel species. Nucleotide sequences of $16 \mathrm{~S}$ rRNA genes obtained in this research and from the GenBank database were aligned, sequence similarities were calculated and a phylogenetic tree generated, bootstrapped with 1000 subsamples and visualized as described in Methods. Abbreviations: R., Rhizobium; Ag., Agrobacterium; Al., Allorhizobium. An extended tree including a wider range of reference sequences is available as supplementary material in IJSEM Online.

R. galegae and related rhizobia has been discussed. One opinion is to give this branch independent genus status (Young \& Haukka, 1996). Another, opposing, suggestion is to combine all the species of Rhizobium, Agrobacterium and Allorhizobium into an emended genus Rhizobium (Young et al., 2001). Our results in this paper show clearly that the $R$. galegae, $R$. huautlense and cluster 2 are a monophyletic group, separated from both the other Rhizobium species and Agrobacterium species. The phylogenetic distances shown in Fig. 3 indicate that the relationships among this group and the Agrobacterium species are as distant as those among the genera Mesorhizobium and Sinorhizobium. Moreover, $R$. galegae and $R$. huautlense have been grouped with Rhizobium mongolense and Rhizobium gallicum in some previous reports (Wang et al., 1998; Peng et al., 2002). Considering the low bootstrap values at the node separating the R. galegae branch and Agrobacterium species in Fig. 3, characterization of more $R$. galegae-related bacteria is needed in order to make a confident taxonomic conclusion about $R$. galegae and related taxa.

\section{DNA G+C contents and DNA-DNA hybridization}

DNA-DNA hybridization was done among reference strains chosen according to the clustering results from numerical taxonomy and the phylogenetic relationships in $16 \mathrm{~S}$ rDNA analyses. DNA G $+\mathrm{C}$ contents and DNA-DNA relatedness values are shown in Table 2. The DNA G $+\mathrm{C}$ content for the isolates from cluster 2 was $59 \cdot 1-60 \cdot 3 \mathrm{~mol} \%\left(T_{\mathrm{m}}\right)$, which is 
Table 2. DNA $G+C$ content and DNA-DNA relatedness among the novel isolates and defined species

$\mathrm{G}+\mathrm{C}$ contents were determined by the $T_{\mathrm{m}}$ method. Results of DNA-DNA hybridizations are mean percentages \pm standard error from three replicates. ND, Not determined.

\begin{tabular}{|c|c|c|}
\hline Species or cluster & $\begin{array}{c}\text { DNA G +C } \\
\text { content }(\mathrm{mol} \%)\end{array}$ & $\begin{array}{c}\text { DNA relatedness with } \\
\text { strain CCBAU } 7190 \mathrm{~B}^{\mathrm{T}}(\%)\end{array}$ \\
\hline \multicolumn{3}{|l|}{ Cluster 2 ( $R$. loessense sp. nov.) } \\
\hline CCBAU 71240 & $59 \cdot 1$ & $81 \cdot 5 \pm 3 \cdot 8$ \\
\hline CCBAU 71264 & $60 \cdot 3$ & $81 \cdot 9 \pm 4 \cdot 0$ \\
\hline CCBAU 71309 & $60 \cdot 3$ & $91 \cdot 0 \pm 2 \cdot 9$ \\
\hline CCBAU 7190A & $59 \cdot 1$ & $86 \cdot 2 \pm 2 \cdot 6$ \\
\hline CCBAU 71291 & $59 \cdot 5$ & $89 \cdot 0 \pm 5 \cdot 0$ \\
\hline CCBAU 71288 & $60 \cdot 2$ & $88 \cdot 6 \pm 4 \cdot 6$ \\
\hline CCBAU $7190 \mathrm{~B}^{\mathrm{T}}$ & $59 \cdot 5$ & 100 \\
\hline CCBAU 71295 & $59 \cdot 1$ & $84 \cdot 7 \pm 3 \cdot 2$ \\
\hline Agrobacterium tumefaciens IAM $13129^{\mathrm{T}}$ & ND & 0 \\
\hline Agrobacterium rubi IAM $13569^{\mathrm{T}}$ & ND & $6 \cdot 2 \pm 1 \cdot 0$ \\
\hline Agrobacterium vitis IAM $14140^{\mathrm{T}}$ & ND & 0 \\
\hline \multicolumn{3}{|l|}{ R. galegae } \\
\hline HAMBI $540^{\mathrm{T}}$ & ND & $40 \cdot 1 \pm 2 \cdot 1$ \\
\hline HAMBI 1185 & ND & $34 \cdot 2 \pm 1 \cdot 6$ \\
\hline \multicolumn{3}{|l|}{ R. huautlense } \\
\hline $\mathrm{S} 02^{\mathrm{T}}$ & ND & $9 \cdot 3 \pm 0 \cdot 6$ \\
\hline S03 & ND & $10 \cdot 5 \pm 1 \cdot 2$ \\
\hline R. giardinii USDA $2914^{\mathrm{T}}$ & ND & $12 \cdot 0 \pm 1 \cdot 8$ \\
\hline R. yanglingense $\mathrm{SH} 22623^{\mathrm{T}}$ & ND & $28 \cdot 2 \pm 2 \cdot 2$ \\
\hline R. indigoferae CCBAU $71042^{\mathrm{T}}$ & ND & $48 \cdot 6 \pm 1 \cdot 3$ \\
\hline R. sullae IS $123^{\mathrm{T}}$ & ND & $21 \cdot 1 \pm 3 \cdot 0$ \\
\hline Rhizobium sp. SDW014 & ND & $28 \cdot 3 \pm 1 \cdot 9$ \\
\hline Rhizobium sp. SDW018 & ND & $37 \cdot 6 \pm 3 \cdot 8$ \\
\hline
\end{tabular}

within the range for Rhizobium (Jordan, 1984). The DNADNA relatedness among the isolates within cluster 2 ranged from $81 \cdot 5$ to $91 \cdot 0 \%$ with a mean of $86 \cdot 1 \%$, indicating that these isolates were also a genomic group.

The DNA-DNA relatedness between the cluster 2 isolate CCBAU $7190 \mathrm{~B}^{\mathrm{T}}$ and reference strains, including the most closely related species $R$. galegae and $R$. huautlense, the recently described species Rhizobium yanglingense (Tan et al., 2001) and Rhizobium indigoferae (Wei et al., 2002) from the Loess Plateau and strains SDW014 and SDW018, representing unnamed rhizobial groups associated with $A$. adsurgens (Gao et al., 2001), varied from 0 to $48 \cdot 6 \%$. Although an intermediate level of DNA-DNA relatedness ( 40 to $48 \%$ ) was detected between isolate CCBAU $7190 \mathrm{~B}^{\mathrm{T}}$ and some reference strains, these values are still much lower than those among strains within the cluster (more than $81 \%$ ). From these results, we conclude that the isolates in cluster 2 formed a single genomic group different from the related species.

Based upon the results of numerical taxonomy, 16S rRNA sequence analysis and DNA-DNA hybridization, we conclude that cluster 2 represents a unique group within the genus Rhizobium. Considering the definition of other rhizobial species and the current criteria for description of new rhizobial taxa (Graham et al., 1991), we propose a novel species, Rhizobium loessense sp. nov., for the isolates within cluster 2 . The distinctive features and host range of this bacterium were investigated for identification purposes.

\section{Distinctive features and host range of the novel group}

Distinctive phenotypic features for cluster 2, R. huautlense, $R$. galegae and some other related species are presented in Table 3. In addition, PCR-RFLP of 16S rRNA genes and host origin are also valuable for distinguishing the novel species from related bacteria.

In cross-nodulation tests, the nine isolates in cluster 2 could share host plants and also nodulated Astragalus adsurgens. Isolate CCBAU $7190 \mathrm{~B}^{\mathrm{T}}$ did not nodulate Astragalus sinicus, Medicago sativa, Galega orientalis, Lotus corniculatus, Vigna sinensis, Glycine max, Trifolium repens, Phaseolus vulgaris or Caragana korshinskii. Since host specificity is an important feature for rhizobia and cross-nodulation has been recommended for definition of novel rhizobia taxa (Graham et al., 1991), we did the cross-nodulation tests. 
Table 3. Distinctive features of Rhizobium loessense sp. nov. and related species

Species/cluster: 1 , cluster 1 ( $n=6) ; 2, R$. loessense sp. nov. $(n=9) ; 3, R$. galegae $(n=2) ; 4, R$. huautlense $(n=2) ; 5$, R. leguminosarum ( $n=2) ; 6, R$. tropici $(n=2) ; 7$, R. hainanense $(n=2) ; 8$, R. etli $(n=2)$. Numbers are percentages of positive strains: + , all strains positive; - , all strains negative; ND, no data available.

\begin{tabular}{|c|c|c|c|c|c|c|c|c|}
\hline Characteristic & 1 & 2 & 3 & 4 & 5 & 6 & 7 & 8 \\
\hline \multicolumn{9}{|l|}{ Utilization as sole carbon source: } \\
\hline D-Amygdalin & + & - & 50 & ND & + & - & - & - \\
\hline D-Arabinose & 50 & - & + & + & + & + & + & + \\
\hline $\mathrm{D}(+)$-Arabitol & + & 67 & - & + & - & 50 & + & + \\
\hline Calcium malonate & - & - & + & ND & + & - & - & - \\
\hline Dulcitol & + & + & + & + & + & - & + & - \\
\hline meso-Erythritol & - & 67 & 50 & - & - & + & + & - \\
\hline Sodium citrate & 67 & - & + & - & + & + & + & + \\
\hline Salicin & + & 90 & + & ND & + & - & - & + \\
\hline D-Ribose & 33 & - & - & ND & + & + & + & + \\
\hline D-Gluconate & 16 & - & 50 & + & - & - & + & + \\
\hline D-Sorbitol & + & - & + & + & + & + & + & + \\
\hline Sucrose & + & 67 & + & + & - & - & + & + \\
\hline Tartrate & - & - & 50 & $\mathrm{ND}$ & 50 & 50 & - & + \\
\hline Trehalose & + & - & + & + & + & + & + & + \\
\hline Xylose & 67 & - & - & + & + & + & + & + \\
\hline Glycine & + & 78 & 50 & - & - & + & + & + \\
\hline \multicolumn{9}{|l|}{ Utilization as sole nitrogen source: } \\
\hline L-Glutamic acid & + & + & + & + & - & + & + & - \\
\hline Glycine & + & + & - & ND & - & + & + & + \\
\hline L-Valine & + & - & + & ND & - & - & + & - \\
\hline \multicolumn{9}{|l|}{ Resistance to $\left(\mu \mathrm{g} \mathrm{ml}^{-1}\right)$ : } \\
\hline Ampicillin (100) & 67 & 21 & + & - & + & + & + & + \\
\hline Chloramphenicol (5) & + & + & - & - & + & + & + & + \\
\hline Chloramphenicol (100) & 50 & - & - & - & - & + & + & - \\
\hline Erythromycin (100) & + & - & + & + & - & - & + & - \\
\hline Kanamycin (50) & - & - & + & + & - & - & - & - \\
\hline Streptomycin (300) & 50 & - & - & - & - & + & - & + \\
\hline \multicolumn{9}{|l|}{ Tolerance of $(\%)$ : } \\
\hline Acridine hydrochloride $(0 \cdot 1)$ & 16 & - & - & - & - & + & + & - \\
\hline Methyl green $(0 \cdot 1)$ & + & - & + & - & + & - & + & + \\
\hline $\mathrm{NaCl}(2 \cdot 0)$ & + & + & - & - & - & + & + & - \\
\hline \multicolumn{9}{|l|}{ Growth at/in: } \\
\hline $\mathrm{pH} 5 \cdot 0$ & - & - & + & - & - & + & + & - \\
\hline $\mathrm{pH} 10 \cdot 0$ & + & + & - & + & + & + & + & + \\
\hline $40^{\circ} \mathrm{C}$ & $\mathrm{ND}$ & ND & - & + & - & - & $\mathrm{ND}$ & ND \\
\hline LB broth & + & - & - & - & - & + & + & - \\
\hline
\end{tabular}

However, we believe that the association between rhizobia and their hosts under laboratory conditions is less important than in the natural environment. Some rhizobia can form nodules with a legume under laboratory conditions, such as R. huautlense on Leucaena leucocephala (Wang et al., 1998), from which they have never been isolated in the field.

\section{Description of Rhizobium loessense sp. nov.}

Rhizobium loessense (lo.es.sen'se. N.L. neut. adj. loessense referring to the Loess Plateau of China, where the bacterium was isolated).
Short, aerobic, Gram-negative, non-spore-forming rods, $0 \cdot 5-0 \cdot 7 \mu \mathrm{m}$ wide by $1 \cdot 8-2 \cdot 1 \mu \mathrm{m}$ long. Colonies are $2-3 \mathrm{~mm}$ in diameter after $2-3$ days on YMA at $28^{\circ} \mathrm{C}$. Strains produce acid in YMA and do not grow in LB medium. Generation time is $2 \cdot 2-3 \cdot 4 \mathrm{~h}$ in PY broth as determined spectrophotometrically. Utilizes D-arabinose, meso-erythritol, Dmannose, sodium citrate, D-ribose, D-sorbitol and dulcitol, but not D-amygdalin, calcium malonate, dulcitol, salicin, Dsodium gluconate or sucrose as sole carbon sources. Utilizes L-glutamic acid and glycine but not $\mathrm{L}$-valine as sole nitrogen sources. Sensitive to $100 \mu \mathrm{g}$ erythromycin $\mathrm{ml}^{-1}$. Cannot grow in medium supplemented with $0 \cdot 1 \%$ methyl green or 
$4 \cdot 0 \% \mathrm{NaCl}$. Strains have been isolated from Astragalus scobwerrimus, Astragalus complanatus and Astragalus chrysopterus and they can nodulate Astragalus adsurgens under laboratory conditions. The DNA G $+\mathrm{C}$ content is $59 \cdot 1-60 \cdot 3 \mathrm{~mol} \%\left(T_{\mathrm{m}}\right)$.

The type strain is CCBAU $7190 \mathrm{~B}^{\mathrm{T}}\left(=\mathrm{AS} 1.3401^{\mathrm{T}}=\mathrm{LMG}\right.$ $\left.21975^{\mathrm{T}}\right)$. Its generation time is $3 \cdot 1 \mathrm{~h}$ and its DNA $\mathrm{G}+\mathrm{C}$ content is $59 \cdot 5 \mathrm{~mol} \%\left(T_{\mathrm{m}}\right)$.

\section{ACKNOWLEDGEMENTS}

This research was a part of projects no. 39730010 and 3000005 supported by the National Science Foundation of China.

\section{REFERENCES}

Allen, O. N. \& Allen, E. K. (1981). The Leguminosae: a Source Book of Characteristics, Uses, and Nodulation. Madison, WI: University of Wisconsin Press.

Chen, W. X., Li, G. S., Qi, Y. L., Wang, E. T., Yuan, H. L. \& Li, J. L. (1991). Rhizobium huakuii sp. nov. isolated from the root nodules of Astragalus sinicus. Int J Syst Bacteriol 41, 275-280.

Chen, W., Wang, E., Wang, S., Li, Y., Chen, X. \& Li, Y. (1995). Characteristics of Rhizobium tianshanense sp. nov., a moderately and slowly growing root nodule bacterium isolated from an arid saline environment in Xinjiang, People's Republic of China. Int J Syst Bacteriol 45, 153-159.

Chen, W.-X., Tan, Z.-Y., Gao, J.-L., Li, Y. \& Wang, E.-T. (1997). Rhizobium hainanense sp. nov., isolated from tropical legumes. Int J Syst Bacteriol 47, 870-873.

Chen, W.-M., Laevens, S., Lee, T.-M., Coenye, T., De Vos, P., Mergeay, M. \& Vandamme, P. (2001). Ralstonia taiwanensis sp. nov., isolated from root nodules of Mimosa species and sputum of a cystic fibrosis patient. Int J Syst Evol Microbiol 51, 1729-1735.

de Lajudie, P., Willems, A., Pot, B. \& 7 other authors (1994). Polyphasic taxonomy of rhizobia: emendation of the genus Sinorhizobium and description of Sinorhizobium meliloti comb. nov., Sinorhizobium saheli sp. nov., and Sinorhizobium teranga sp. nov. Int J Syst Bacteriol 44, 715-733.

de Lajudie, P., Willems, A., Nick, G. \& 9 other authors (1998a). Characterization of tropical tree rhizobia and description of Mesorhizobium plurifarium sp. nov. Int J Syst Bacteriol 48, 369-382.

de Lajudie, P., Laurent-Fulele, E., Willems, A., Torck, U., Coopman, R., Collins, M. D., Kersters, K., Dreyfus, B. \& Gillis, M. (1998b). Allorhizobium undicola gen. nov., sp. nov., nitrogen-fixing bacteria that efficiently nodulate Neptunia natans in Senegal. Int J Syst Bacteriol 48, 1277-1290.

De Ley, J. (1970). Reexamination of the association between melting point, buoyant density, and chemical base composition of deoxyribonucleic acid. J Bacteriol 101, 738-754.

De Ley, J., Cattoir, H. \& Reynaerts, A. (1970). The quantitative measurement of DNA hybridization from renaturation rates. Eur J Biochem 12, 133-142.

Gao, J. L., Sun, J. G., Li, Y., Wang, E. T. \& Chen, W. X. (1994). Numerical taxonomy and DNA relatedness of tropical rhizobia isolated from Hainan Province, China. Int J Syst Bacteriol 44, 151-158.

Gao, J., Terefework, Z., Chen, W. \& Lindström, K. (2001). Genetic diversity of rhizobia isolated from Astragalus adsurgens growing in different geographical regions of China. J Biotechnol 91, 155-168.

Genetics Computer Group (1995). Program Manual for the Wisconsin Package, Version 8. Madison, WI: Genetics Computer Group.

Graham, P. H., Sadowsky, M. J., Keyser, H. H. \& 8 other authors (1991). Proposed minimal standards for the description of new genera and species of root- and stem-nodulation bacteria. Int J Syst Bacteriol 41, 582-587.

Jordan, D. C. (1984). Family III. Rhizobiaceae Conn 1938, 321 ${ }^{\mathrm{AL}}$. In Bergey's Manual of Systematic Bacteriology, vol. 1, pp. 234-235. Edited by N. R. Krieg \& J. G. Holt. Baltimore: Williams \& Wilkins. Laguerre, G., Allard, M., Revoy, F. \& Amarger, N. (1994). Rapid identification of rhizobia by restriction fragment length polymorphism analysis of PCR-amplified 16S rRNA genes. Appl Environ Microbiol 60, 56-63.

Laguerre, G., van Berkum, P., Amarger, N. \& Prévost, D. (1997). Genetic diversity of rhizobial symbionts isolated from legume species within the genera Astragalus, Oxytropis, and Onobrychis. Appl Environ Microbiol 63, 4748-4758.

Marmur, J. (1961). A procedure for the isolation of DNA from microorganisms. J Mol Biol 3, 208-218.

Moulin, L., Munive, A., Dreyfus, B. \& Boivin-Masson, C. (2001). Nodulation of legumes by members of the $\beta$-subclass of Proteobacteria. Nature 411, 948-950.

Murooka, Y., Xu, Y. \& Sanada, K. (1993). Formation of root nodules by Rhizobium huakuii biovar renge, bv. nov. on Astragalus sinicus cv. Japan. Ferment Bioeng 78, 38-44.

Novikova, N. I., Pavlova, E. A., Vorobjev, N. I. \& Limeshchenko, E. V. (1994). Numerical taxonomy of Rhizobium strains from legumes of the temperate zone. Int J Syst Bacteriol 44, 734-742.

Page, R. D. M. (1996). TreeView: an application to display phylogenetic trees on personal computers. Comput Appl Biosci 12, 357-358.

Peng, G. X., Tan, Z. Y., Wang, E. T., Reinhold-Hurek, B., Chen, W. F. \& Chen, W. X. (2002). Identification of isolates from soybean nodules in Xinjiang Region as Sinorhizobium xinjiangense and genetic differentiation of $S$. xinjiangense from Sinorhizobium fredii. Int J Syst Evol Microbiol 52, 457-462.

Sneath, P. H. A. \& Sokal, R. B. (1973). Numerical Taxonomy. The Principles and Practice of Numerical Classification. San Francisco: W. H. Freeman.

Squartini, A., Struffi, P., Döring, H. \& 10 other authors (2002). Rhizobium sullae sp. nov. (formerly 'Rhizobium hedysari'), the rootnodule microsymbiont of Hedysarum coronarium L. Int J Syst Evol Microbiol 52, 1267-1276.

Tan, Z.-Y., Xu, X.-D., Wang, E.-T., Gao, J.-L., Martínez-Romero, E. \& Chen, W.-X. (1997). Phylogenetic and genetic relationships of Mesorhizobium tianshanense and related rhizobia. Int $J$ Syst Bacteriol 47, 874-879.

Tan, Z. Y., Wang, E. T., Peng, G. X., Zhu, M. E., Martínez-Romero, E. \& Chen, W. X. (1999). Characterization of bacteria isolated from wild legumes in the north-western regions of China. Int J Syst Bacteriol 49, 1457-1469.

Tan, Z. Y., Kan, F. L., Peng, G. X., Wang, E. T., Reinhold-Hurek, B. \& Chen, W. X. (2001). Rhizobium yanglingense sp. nov., isolated from arid and semi-arid regions in China. Int J Syst Evol Microbiol 51, 909-914.

Thompson, J. D., Higgins, D. G. \& Gibson, T. J. (1994). CLUSTAL W: improving the sensitivity of progressive multiple sequence alignment through sequence weighting, position-specific gap penalties and weight matrix choice. Nucleic Acids Res 22, 4673-4680. 
Vincent, J. M. (1970). A Manual for the Practical Study of Root Nodule Bacteria. Oxford: Blackwell Scientific.

Wang, S. Y. \& Chen, W. X. (1996). Numerical taxonomy and DNA relatedness of rhizobia isolated from Astragalus spp. In Diversity and Taxonomy of Rhizobia, pp. 79-84. Edited by F. D. Li, D. Lie, W. X. Chen \& J. C. Zhou. Beijing: China Agricultural Scientech Press.

Wang, E. T., van Berkum, P., Beyene, D., Sui, X. H., Dorado, O., Chen, W. X. \& Martínez-Romero, E. (1998). Rhizobium huautlense sp. nov., a symbiont of Sesbania herbacea that has a close phylogenetic relationship with Rhizobium galegae. Int J Syst Bacteriol 48, 687-699.

Wang, E. T., van Berkum, P., Sui, X. H., Beyene, D., Chen, W. X. \& Martínez-Romero, E. (1999). Diversity of rhizobia associated with Amorpha fruticosa isolated from Chinese soils and description of Mesorhizobium amorphae sp. nov. Int J Syst Bacteriol 49, 51-65.

Wdowiak, S. \& Malek, W. (2000). Numerical analysis of Astragalus cicer microsymbionts. Curr Microbiol 41, 142-148.

Wei, G. H., Wang, E. T., Tan, Z. Y., Zhu, M. E. \& Chen, W. X. (2002). Rhizobium indigoferae sp. nov. and Sinorhizobium kummerowiae sp. nov., respectively isolated from Indigofera spp. and Kummerowia stipulacea. Int J Syst Evol Microbiol 52, 2231-2239.

Yao, Z. Y., Kan, F. L., Wang, E. T, Wei. G. H. \& Chen, W. X. (2002). Characterization of rhizobia that nodulate legume species of the genus Lespedeza and description of Bradyrhizobium yuanmingense sp. nov. Int J Syst Evol Microbiol 52, 2219-2230.

Yelton, M. M., Yang, S. S., Edie, S. A. \& Lim, S. T. (1983). Characterization of an effective salt-tolerant, fast-growing strain of Rhizobium japonicum. J Gen Microbiol 129, 1537-1547.

Young, J. P. W. \& Haukka, K. E. (1996). Diversity and phylogeny of rhizobia. New Phytol 133, 87-94.

Young, J. M., Kuykendall, L. D., Martínez-Romero, E., Kerr, A. \& Sawada, H. (2001). A revision of Rhizobium Frank 1889, with an emended description of the genus, and the inclusion of all species of Agrobacterium Conn 1942 and Allorhizobium undicola de Lajudie et al. 1998 as new combinations: Rhizobium radiobacter, $R$. rhizogenes, $R$. rubi, $R$. undicola and $R$. vitis. Int $J$ Syst Evol Microbiol 51, 89-103. 